\title{
Ectoparasites (Feather Mites) on Wild Birds at Some Localities in Egypt
}

\author{
A. M. Metwally*; Wafaa F. Abd-Elhameed Ahmed ${ }^{* *}$ and Noura, M. Barakat ${ }^{* *}$ \\ *Faculty of Agriculture, Al-Azhar University, Cairo, Egypt. \\ ${ }^{* *}$ Faculty of Home Economics, Al-Azhar University, Tanta, Egypt.
}

\begin{abstract}
The present study was conducted for two years (2016-2018) to throw some light on the acarofauna feather bird mites (Arachnida: Acari: (Astigmata) of some wild birds in some Egypt governorates. The study revealed the presence of 30 species of feather bird mites, belonging to 9 families and one suborder (Astigmata) were collected from 21 species within 8 families. Mites were extracted using modified Tullgren funnel and mounted in Hoyer's medium on microscopic slides for examination. The parasitic feather mites detected in the present study included feather mites of families Alloptidae, Analgidae, Avenzoariidae, Proctophyllodidae, Pterolichidae, Trouessartiidae, Xolalgidae and Falcuferidae. The present study showed that wild birds in Egypt harbor various species of ectoparasitic feather mites.
\end{abstract}

Key words: Mites, Feather mites, Wild birds, A-stigmata.

\section{INTRODUCTION}

To date, the biodiversity of feather mites has been most thoroughly explored in Europe. Investigations have been carried out in more than 15 countries during the second half of the 20th century (for major references see Mironov, 1996, 1997). Recently, Proctor and Owens (2000) reviewed the role that mites play in the lives of birds. The best studied mites of birds are detrimental parasites. Among them, some astigmatid mites (suborder Astigmata, order Acariformes) seriously weaken their hosts by feeding on feather pith, tunnelling outwards through the feather, burrowing into the skin and other parts of feather follicles, and invading the lungs, tracheae and air sacs. Feather mites are a vast group of astigmatid mites that are permanent parasites or symbiotes of birds, and live on their plumage or skin. Feather mites are abundant on many different species of birds, but their biology is very poorly known. Feather mites in the superfamilies: Analgoidea, Freyanoidea and Pterolichoidea, are considered to be "true" feather mites (Proctor 2003).

Feather mites (Acari: Astigmata: Analgoidea, Pterolichoidea) are the most diverse groups of arthropods found on birds (Clayton et al., 2010), with about 2,500 described species representing more than 30 families (Mironov and Proctor, 2011).

Villa et al., (2013) found 8 genera of feather mites; the most prevalent genus was Mesalgoides (53-55\%), followed by Trouessartia (40-45\%), Amerodectes and Proctophyllodes (26-33\%), Xolalgoides (2127\%), Analges and Strelkoviacarus (0-6\%), and Dermoglyphus (2-4\%). Fifteen feather mite taxa distributed into the families Analgidae, Proctophyllodidae, Psoroptoididae, Pteronyssidae, Xolalgidae, Trouessartiidae, Falculiferidae and Gabuciniidae Silva et al., (2015). Rodrigues et al., (2015) recorded 19 feather mite species belonging to four families of the superfamily Analgoidea (Analgidae, Proctophyllodidae, Psoroptoididae and Trouessartiidae).

Faunistic studies about mites of birds in Egypt are limited. First reports of mites from Egyptian birds were published by Rakha (1980) for Astigmata and by Zaher (1986) for mites of various orders. Abd-Alla (1993) also provided taxonomic information about mites reported from wild birds. Sakr (2017) found feather mites include 32 species belonging to 15 families. To our knowledge, there is no taxonomic enough information source that contains the mite fauna of Egyptian birds that helps researchers find out what taxa have been reported to date and where they were found. To establish a baseline and enhance knowledge for further work on birds' mite fauna, this work presents data on the taxonomy and occurrence of feather bird mites (Astigmata) associated with wild birds in Egypt.

\section{MATERIALS AND METHODS}

Mites were collected from freshly killed birds from different locations in some Egypt governorates, during (2016 - 2018). Birds were trapped from different areas in and around Egypt. A total of 20 wild bird species (174 individuals) were examined. The wild birds were represented by Hoopoe (10); Senegal thick-knee (8); Spur-winged Plover (8); Palm dove (12); Rock Dove (10); Pied king fisher (6); Senegal coucal (8), Egyptian kestrel (5); Hooded Crow (12); White wagtail (5); House sparrow, (20); Swallow (12); Common bulbul (6); Cattle egret (20); Little egret (12); Black-crowned Night heron (5); Common Snipe (5); Little owl (5) and Black-winged Kite (5).

The plumage of the bird was thoroughly brushed by a fine camelhair brush onto a white tray for the collection of mites. The feathers of the head, the neck, 
under the wings, body, legs and cloaca were collected from each bird and placed individually in modified Berlese funnels for 24 hours to collect the motile as well as quill mites into Petri dishes (Zumpt 1961). For collecting immotile or dead mites, a technique adapted from Lipovsky (1951) was used. Feathers were immersed in a beaker containing a detergent. The beaker was shaken for about 30 minutes, then the feathers were separated and the sedimented mites were isolated using a stereomicroscope. For permanent preparation, mites were cleared in lactic acid, washed in ethyl alcohol and mounted in Hoyer's medium (Krantz 1978). The cleared specimens were counted examined and identified by phase contrast microscope. Mites were identified to species using the keys given by Baker et al. (1956), Zumpt (1961), Fain (1965), Kethly (1970), Smiley (1970), Hughes (1976) and Krantz (1978).

\section{RESULTS AND DISCUSSION}

Data in Table (1) revealed the presence of 34 feather mite species belonging to (15) genera under 8 families; these are belonging to one order and one suborder.

A- Order Acariformes: Acariformes was represented by one Sub-order (Acarididae).

A-1- Suborder: Acarididae was represented by eight families (Alloptidae, Trouessartiidae, Analgidae, Avenzoariidae, Proctophyllodidae, Pterolichidae, Xolalgidae Falcuferidae).

Family Alloptidae: This family was represented by three species Alloptes limosae, Laminalloptes simplex which collected from (Bubulcus ibis ibis, Egretta garzetta garzetta, Gallinula cloropus and Hoplopterus spinosus) with number from and Laminalloptes minor from (Bubulcus ibis ibis) only.

Family Analgidae: This family was represented by three species these species were Analges sp. from (Centropus senegalensis aegyptius, Columbia livia, Passer domesticus niloticus, Pycnonotus barbatus, Streptopelia senegalensis aegyptiaca and Upupa epops major); Analges corvinus from (Corvus cornix sardonius and Passer domesticus niloticus); Analges passerinus from (Passer domesticus niloticus and Upupa epops major); Analges spiniger from (Passer domesticus niloticus, Centropus senegalensis aegyptius and Pycnonotus barbatus) ; Analges turdinus from Turdus merula; Megninia columbae from (Columbia livia and Streptopelia senegalensis aegyptiaca); and Temnalges sp. from (Centropus senegalensis aegyptius and Columbia livia).
Family Avenzoariidae: This family was represented by six mite species, Avenzoaria calidridis and Avenzoaria totani were from (Gallinago gallinago); Avenzoaria sp. from (Streptopelia senegalensis aegyptiaca, Columbia livia and Motacilla alba alba); Scutomegninia microfalcifera from (Hirundo rustica savignii); Zachkvatkinia turdinus and Zachkvatkinia sp. from (Burhinus senegalensis, Hoplopterus spinosus and Gallinago gallinago).

Family Proctophyllodidae: This family was represented by eight mite species Brephosceles forficiger from (Upupa epops major) Brephosceles sp. from ( Ceryle rudis) and Brephosceles palagicus from (Hirundo rustica savignii, Bubulcus ibis ibis, Egretta garzetta garzetta and Nycticorax nycticorax nycticorax); Proctophyllodes sp. from (Upupa epops major, Streptopelia senegalensis aegyptiaca Columbia livia, Ceryle rudis and Passer domesticus niloticus); Proctophyllodes Sylvia from (Upupa epops major and Corvus cornix sardonius); Proctophyllodes troncatus, Brephosceles orientalis from (Upupa epops major and Passer domesticus niloticus) Proctophyllodes weigoldi from (Turdus merula).

Family Pterolichidae: This family was represented by one mite species Montchadskiana securicata from (Elanus coeruleus and Falco tinnunculus rupicolaeformis).

Family Trouessartiidae: This family was represented by six mite species Trouessartia sp., from (Corvus cornix sardonius and Passer domesticus niloticus) ; Trouessartia africana from (Corvus cornix sardonius, Hirundo rustica savignii, Passer domesticus niloticus, and Turdus merula) ; Trouessartia incise from (Corvus cornix sardonius, Passer domesticus niloticus and Turdus merula) from Trouessartia unicolor from (Corvus cornix sardonius, Motacilla alba alba, Passer domesticus niloticus and Turdus merula) Trouessartia eulobis from (Motacilla alba alba) and Trouessartia bifurcate from (Hirundo rustica savignii and Motacilla alba alba).

Family Xolalgidae: This family was represented by two mite species Xolalgoides palmai from (Falco tinnunculus rupicolaeformis) and Leptosphyra sp. from (Athene noctua glaux and Elanus coeruleus).

Family Falcuferidae: This family was represented by one mite species Byresalges talpacoti from (Columbia livia).

Data reaveled that; the highest infestation with avian mites was in House sparrow, Passer domesticus niloticus which infected with twelve mite species 
Table (1): Feather bird mites of some wild bird species

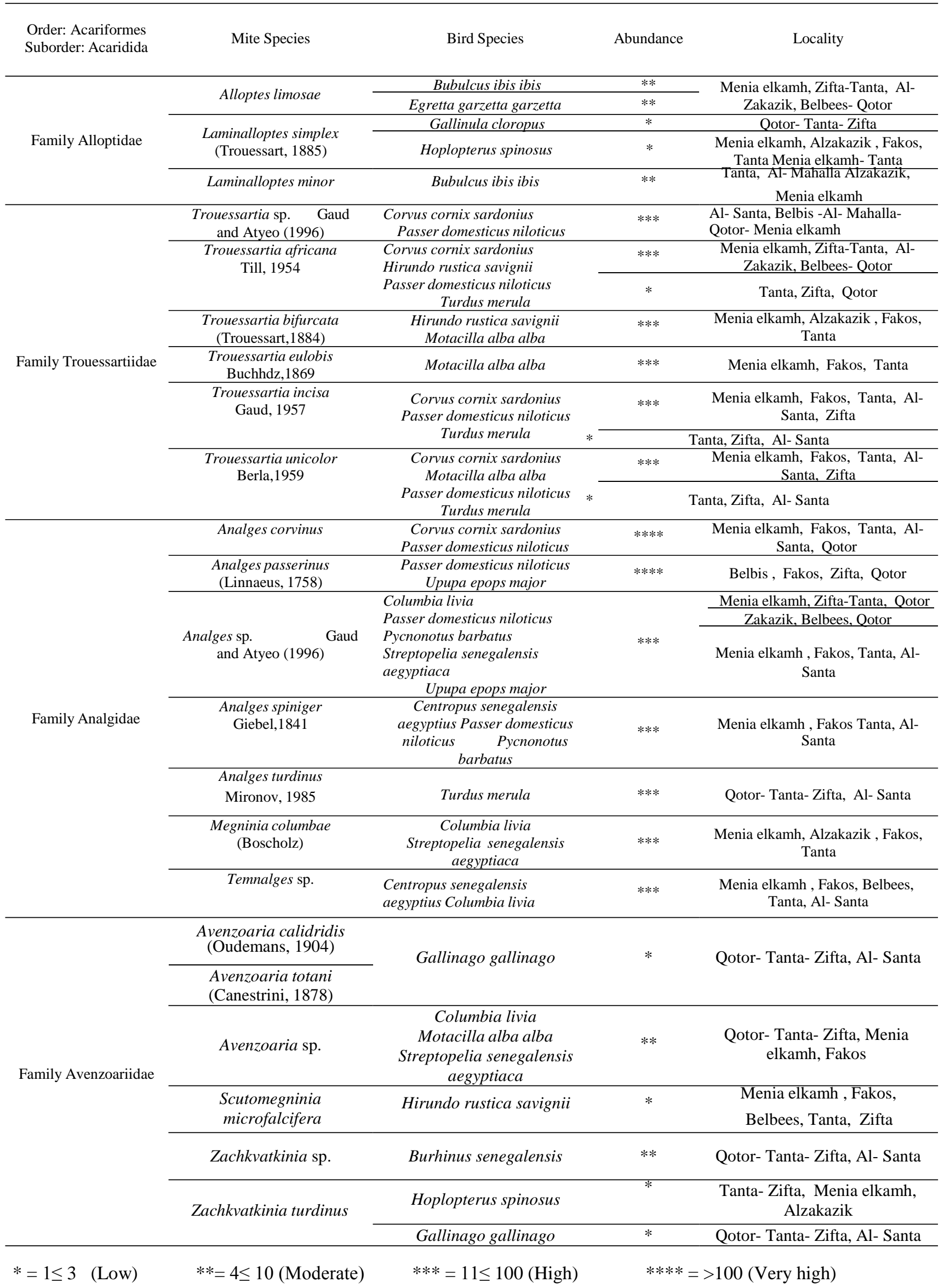


Continue:

\begin{tabular}{|c|c|c|c|c|}
\hline $\begin{array}{l}\text { Order: Acariformes } \\
\text { Suborder: Acaridida }\end{array}$ & Mite Species & Bird Species & Abundance & Locality \\
\hline \multirow{10}{*}{$\begin{array}{c}\text { Family } \\
\text { Proctophyllodidae }\end{array}$} & $\begin{array}{c}\text { Brephosceles forficiger } \\
\text { Magnin and Trouessart, } \\
1884 \\
\end{array}$ & Upupa epops major & $* *$ & Zifta, Menia elkamh \\
\hline & $\begin{array}{l}\text { Brephosceles orientalis } \\
\text { (Gaud) }\end{array}$ & $\begin{array}{c}\text { Passer domesticus niloticus } \\
\text { Upupa epops major }\end{array}$ & $* * *$ & Menia elkamh, Belbees, Qotor \\
\hline & \multirow[t]{2}{*}{$\begin{array}{l}\text { Brephosceles palagicus } \\
\text { Vitzthum } 1921\end{array}$} & $\begin{array}{c}\text { Bubulcus ibis ibis } \\
\text { Egretta garzetta garzetta } \\
\text { Hirundo rustica savignii }\end{array}$ & $* * *$ & $\begin{array}{l}\text { Menia elkamh, Belbees, Al- } \\
\text { Zakazik, Tanta, , Zifta, Qotor }\end{array}$ \\
\hline & & $\begin{array}{c}\text { Nycticorax nycticorax } \\
\text { nycticorax } \\
\end{array}$ & $* *$ & Zifta, Tanta, Qotor \\
\hline & Brephosceles sp. & Ceryle rudis & $* * *$ & $\begin{array}{c}\text { Menia elkamh, Zifta-Tanta, } \\
\text { Al-Zakazik }\end{array}$ \\
\hline & \multirow{2}{*}{$\begin{array}{c}\text { Proctophyllodes sp. } \\
\text { Gaud and Atyeo ,1996 }\end{array}$} & Ceryle rudis & $* * *$ & Qotor- Tanta- Zifta \\
\hline & & $\begin{array}{l}\quad \text { Columbia livia } \\
\text { Passer domesticus niloticus } \\
\text { Streptopelia senegalensis } \\
\text { aegyptiaca Upupa epops } \\
\text { major } \\
\end{array}$ & $* * * *$ & $\begin{array}{l}\text { Menia elkamh , } \\
\text { Al-Zakazik, } \\
\text { Zifta-Tanta }\end{array}$ \\
\hline & $\begin{array}{c}\text { Proctophyllodes Sylvia } \\
\text { Gaud, } 1957 \\
\end{array}$ & $\begin{array}{r}\text { Corvus cornix sardonius } \\
\text { Upupa epops major }\end{array}$ & $* * *$ & $\begin{array}{c}\text { Menia elkamh, Belbees , } \\
\text { Fakos, Tanta }\end{array}$ \\
\hline & $\begin{array}{c}\text { Proctophyllodes } \\
\text { troncatus Robin, } 1877\end{array}$ & $\begin{array}{c}\text { Passer domesticus niloticus } \\
\text { Upupa epops major }\end{array}$ & $* * *$ & $\begin{array}{c}\text { Belbees, Alzakazik, Fakos, } \\
\text { Zifta-Tanta }\end{array}$ \\
\hline & $\begin{array}{c}\text { Proctophyllodes } \\
\text { weigoldi Vitzthum, } \\
1922 \\
\end{array}$ & Turdus merula & $* * *$ & Al- Santa, Al- Mahalla- Qotor \\
\hline \multirow{2}{*}{ Family Pterolichidae } & \multirow{2}{*}{$\begin{array}{l}\text { Montchadskiana } \\
\text { securicata }\end{array}$} & Elanus coeruleus & * & Al- Santa, Zifta-Tanta \\
\hline & & $\begin{array}{l}\text { Falco tinnunculus } \\
\text { rupicolaeformis }\end{array}$ & $*$ & $\begin{array}{l}\text { Al- Santa, Al- Mahalla- Qotor, } \\
\text { Tanta }\end{array}$ \\
\hline \multirow[t]{2}{*}{ Family Xolalgidae } & $\begin{array}{l}\text { Leptosphyra sp. } \\
\text { (Trouessart) }\end{array}$ & $\begin{array}{l}\text { Elanus coeruleus } \\
\text { Athene noctua glaux }\end{array}$ & $* * *$ & $\begin{array}{c}\text { Zifta , Al- Mahalla- Qotor, } \\
\text { Tanta } \\
\end{array}$ \\
\hline & $\begin{array}{l}\text { Xolalgoides palmai } \\
\text { Mironov and Perez }\end{array}$ & $\begin{array}{l}\text { Falco tinnunculus } \\
\text { rupicolaeformis }\end{array}$ & $*$ & $\begin{array}{c}\text { Menia elkamh, Alzakazik } \\
\text { Fakos, Zifta-Tanta }\end{array}$ \\
\hline Family Falcuferidae & Byresalges talpacoti & Columbia livia & $* *$ & $\begin{array}{l}\text { Menia elkamh, Alzakazik, } \\
\text { Fakos, Zifta-Tanta }\end{array}$ \\
\hline
\end{tabular}

specially in breeding season, while the lowest infestation with avian mites were Common bulbul, Moorhen and Little owl which infected with two species of mites. In addition to, results indicated to the dominant avian feather mites family was the Proctophyllodidae.

These findings agree with (Lalitha and Alwar, 1961; Alwar, 1970; Rakha, 1980; Abd-Allah, 1993 and Pavlovic, 2003).

The obtained data agree with (Gaud and Atyeo, 1996; Proctor, 2003) found the families Proctophyllodidae and Trouessartiidae are predominately associated with passerines, while members of the families Analgidae and Psoroptoididae are known from various orders of birds. Rodrigues et al., (2015) recorded 19 feather mite species belonging to four families of the superfamily Analgoidea (Analgidae,
Proctophyllodidae, Psoroptoididae and Trouessartiidae). Fifteen feather mite taxa distributed into the families Analgidae, Proctophyllodidae, Psoroptoididae, Pteronyssidae, Xolalgidae, Trouessartiidae, Falculiferidae and Gabuciniidae. Silva et al. (2015).

Likewise; the obtained data in agreement with Sakr (2017) found that; Feather mites, these include 32 species belonging to 15 families: These species were Temnalges sp. follow Analgidae; Lasioseius lindqusti, Lasioseius peritremus follow Ascidae; Avenzoaria sp.1, Avenzoaria sp.2 follow Avenzoariidae; Acaropsellina sollers, Cheletomorpha lepidoptrerom, Cheyletus badryi follow Cheyletidae; Dermoglyphus columbae, Dermoglyphus sp. follow Dermoglyphidae; Byresalges talpacoti, Pterophagus spilosikyus follow Falculiferidae; Androlaelaps casalis, Eulaelaps novus, Eulaelaps stabularis, Hypoaspis orientalis, Hypoaspis wahabi follow Laelapidae; 
Cryptonyssus desultorius follow Macronyssidae; Proctophyllodes acanthicaulus follow Proctophyllodidae; Dermatophagoides farinae, Dermatophagoides pteronyssus, Euroglyphus maynei, Pyroglyphus africanus, Pyroglyphus sp.1, Pyroglyphus sp.2, Pyroglyphus sp.3 follow Pyroglyphidae; Raphignathus sp. follow Raphignathidae; Trichouropoda patavina follow Trematuridae; Uroobovella krantzi follow Urodinychidae; Chiropturopoda bakeri follow Uropodidae and Leptosphyra sp.1, Leptosphyra sp.2 follow Xolagidae.

Finally, from the forgoing study it can be concluded that wild birds play an important role as active vectors for dispersion and spreading of parasitic mites. Hence, much more work would be necessary in order to construct an ecological map of mite distribution allover Egypt and to describe a specific way for control such parasitic group of mites that threatens birds' life and productivity.

\section{REFERENCES}

Abd-Alla, A.A. 1993. Studies on mites associated with wild birds. M.Sc. Thesis, Fac. Agric. AlAzhar Cairo, Egypt. pp. 223.

Abo-Shnaf, R.; Romeih, A. H. M. and Allam, S. F. 2008. Biodiversity of mites associated with parrots and peacocks in Giza Zoo, Egypt. Acarines, Vol. 2: 27-30.

Alwar, V. S. 1970. Feather mites of poultry in India. Ceylon V. J., Vol. 18 (3): 61-65.

Baker, E.W.; Evans, T.M.; Gold, D.G.; Hull, W.B. and Keegan, H.L.1956. A manual of parasitic mites of medical or economic importance. National Pest Control Association, New York. 170

Clayton, D. H. ; Koop, J. A. H.; Harbison, C. W. ; Moyer, B. R. and Bush, S. E. 2010. How birds combat ectoparasites. Open Ornithology Journal 3: 41-71.

Dabert, J., and Mironov, S. V. 1999. Origin and evolution of feather mites (Astigmata). Experimental and Applied Acarology, 23, 437454. https:// doi.org/10.1023/ A:1006180705101

Fain, A. 1965. A review of the family Epidermoptidae parasitic on the skin of birds (Acarina: Sarcoptiformes) part III Konink acad. Wetensch, Lett Schone Kunsten Belg (Wetensch), 27 (84): 176 pp.

Galván, I., Barba, E., Piculo, R., Cantó, J.L., Cortés, V., Monrós, J.S., Atiénzar, F., and Proctor, H.C. 2008. Feather mites and birds: an interaction mediated by uropygial gland size? Journal of Evolutionary Biology, 21: 133-145.

Gaud, J. and Atyeo, W.T. 1996. Feather mites of the world (Acarina, Astigmata): the supraspecific taxa
(Part. I). Annales du Musée Royal de l'Afrique Centrale, vol. 277, p. 1-187.

Hughes, A.M. 1976. The mites of stored food and houses. Tech. Bull. Minist. Agric. Fisf. Fo. 9: $1-400$.

Kethly, J.B. 1970. A revision of the family Syringophilidae (Prostigmata: Acarina). Contrib. Amer. Ento. Inst. 5(6): 1-76

Krantz, G.W. 1978. A manual of acarology. Oregon State Univ. Book stores, Inc., Corvallis, USA. $2^{\text {nd }}$ ed. 509 pp.

Lalitha, C. M. and Alwar, V. S. 1961. Notes on feather mites of poultry in Madras (II). Indian V. J., Vol.38 (l): 36-38.

Lipovsky, L.J. 1951. A washing method of ectoparasite recovery with particular reference to chiggers (Acarina Trombiculidae). J. Kansas Ent. Soc. 24: $151-156$.

Mironov and Proctor 2011. Four new species of the family Pteronyssidae (Astigmata: Analgoidea) from laughing-thrushes (Passeriformes: Timaliidae) in China. Acarina 19: 35-51.

O'Connor, B.M. 2009. Cohort Astigmatina. In: Krantz G. W. and D. E. Walter (eds.): A manual of acarology. Third edition. Texas Tech. University Press, pp. $565-657$.

Pavlovic, I. 2003. Ectoparasites in poultry- Acaridae. Zivinarstvo, Vol. 38(10): 21-22.

Proctor, H. and Owens, I. 2000. Mites and birds: diversity, parasitism and coevolution. Trends in Ecology \& Evolution, vol. 15, no. 9, p. 358-364. http://dx.doi.org/10.1016/S0169- 5347(00)019248. PMid:10931667.

Proctor, H.C. 2003. Feather mites (Acari: Astigmata): ecology, behavior, and evolution. Annual Review of Entomology, vol. 48, no. 1, p. 185-209. http://dx.doi.org/10.1146/annurev. ento.48.091801.112725. PMid:12208818.

Rakha, M. A. 1980. Taxonomical and biological studies on some astigmatid mites of birds. Ph.D. Thesis, Fac. Agric., Cairo Univ., Egypt.pp.384.

Rodrigues, P.; Mironov, S.; Sychra, O.; Resendes, R. and Literak, I. (2015). Feather mites (Acari, Astigmata) from Azorean passerines (Aves, Passeriformes): lower species richness compared to European mainland, Parasite, Vol. 22(8):1-7.

Silva, H.M.; Hernandes, F.A. and Pichorim, M. 2015. Feather mites (Acari, Astigmata) associated with birds in an Atlantic Forest fragment in Northeastern Brazil. Braz. J. Biol., 75 (3): 726-735.

Smiley, R.L. 1970. A review of the family Cheyletiellidae (Acarina). Ann. Ent. Soc. Amer. 63 (4): 1056 - 1078.

Villa, S. M.; Le Bohec, C.; Koop, J. A. H.; Proctor, H. C., and Clayton, D. H. 2013. Diversity of 
Feather Mites (Acari: Astigmata) on Darwin's Finches. Journal of Parasitology, 99(5), 756762. https://doi. org/10.1645/12-112.1

Zaher M. A. (1986). Survey and Ecological

Studies on Phytophagous, Predaceous and

Soil Mites in Egypt. II-B: Predaceous and
Non Phytophagous Mites. E. G. ARS-30, GrantNo. FG-E G-139.

Zumpt, F. (1961). The arthropod parasites of vertebrates in Africa, South of the Sahara, Ethiopian region (Chelicerata). South Africa Vol. I: 185 - 352. 